\title{
Prevalence of Anaplasma phagocytophilum and Borrelia burgdorferi sensu lato, in Ixodes ricinus Parasitising on Red Foxes (Vulpes vulpes) from Romania
}

\author{
Mirabela Oana DUMITRACHE ${ }^{1 *}$, Gianluca D’AMICO ${ }^{1}$, Călin Mircea GHERMAN ${ }^{1}$, Ioana Adriana MATEI ${ }^{1}$, \\ Angela Monica IONICĂ $\breve{ }^{1}$, Anamaria Ioana PAŞTIU ${ }^{1,2}$, Anamaria BALEA ${ }^{1}$, Barabási Sándor SIKÓ ${ }^{3}$, Dan \\ Traian IONESCU ${ }^{4}$, Andrei Daniel MIHALCA ${ }^{1}$ \\ ${ }^{1}$ Department of Parasitology and Parasitic Diseases, University of Agricultural Sciences and Veterinary \\ Medicine Cluj-Napoca, Calea Mănăștur 3-5, Cluj-Napoca 400372, Romania \\ ${ }^{2}$ Department of Infectious Diseases, University of Agricultural Sciences and Veterinary Medicine Cluj- \\ Napoca, Calea Mănăştur 3-5, Cluj-Napoca 400372, Romania \\ ${ }^{3}$ Department of Ecological and Biotechnological Systems, Faculty of Environmental Science, Babeş - \\ Bolyai University, 14 Stadionului Street, 520064 Sfântu Gheorghe, Romania \\ ${ }^{4}$ Department of Game and Wildlife, Faculty of Silviculture and Forestry Engineering, Transilvania \\ University, Şirul Beethoven 1, 500123 Braşov, Romania \\ Corresponding author: mirabela.dumitrache@usamvcluj.ro
}

Bulletin UASVM Veterinary Medicine 72(1) / 2015,

Print ISSN 1843-5270; Electronic ISSN 1843-5378

DOI:10.15835/buasvmcn-vm: 11039

\begin{abstract}
Among wild carnivores, red foxes (Vulpes vulpes) are one of the most adapted to anthropic ecosystems and one of the most abundant ones living in close proximity to humans. They are well recognized as important natural reservoirs for a large number of zoonotic agents in Europe, including ticks and tick-borne pathogens. The aim of our study was to establish the prevalence of two zoonotic tick-borne pathogens, Anaplasma phagocytophilum and Borrelia burgdorferi sensu lato (s.l.), in Ixodes ricinus ticks collected from red foxes. A total number of 216 red foxes, from 9 counties,were investigated and 204 Ixodes ricinus ticks, of all developmental stages were collected. PCR was performed on all samples to detect B. burgdorferi s.l. and A. phagocytophilum DNA. Only A. phagocytophilum was detected with an overall prevalence of $4.4 \%$. As foxes represent a good model of sentinel species, further studies on the structure of tick communities correlated with the presence of tick-borne pathogens, can be suggestive for the risk posed for public health.
\end{abstract}

Keywords: Anaplasma phagocytophilum, Borrelia burgdorferi s.l., Ixodes ricinus, Vulpes vulpes.

\section{INTRODUCTION}

Among wild carnivores, red foxes (Vulpes vulpes) are one of the most adapted to anthropic ecosystems and one of the most abundant ones living in close proximity to humans.It is also well recognised that these animals are common hosts for different species of ectoparasites like lice, fleas, mites and ticks. Red foxes are playing an important role in the ecoepidemiology of tick- transmitted microbes. Foxes act as reservoir host for a large number of zoonotic agents in Europe, including tick-borne pathogens and as host for ticks in certain areas (Martínez-Carrasco et al., 2007), posing a great risk from the public health perspective (Jongejan and Uilenberg, 2004). In this frame, our study aimed to investigate the prevalence of two zoonotic tick-borne pathogens, Anaplasma phagocytophilum and Borrelia 
burgdorferi sensu lato (s.l.), in Ixodes ricinus ticks collected from red foxes in Romania.

\section{MATERIALS AND METHODS}

The study was conducted in Romania, between November 2011 and September 2014. A total number of 216 red foxes, from 9 counties, collected by the National Sanitary Veterinary and Food Safety Authority during campaigns for rabies screening, were examined. All the animals which were negative for rabies were transferred to the Parasitology Department of the Faculty of Veterinary Medicine in Cluj-Napoca, according to the current laws on dead animals transport and zoonotic risks. A macroscopic inspection was performed on all animals and all parasitizing ticks were collected and preserved in absolute ethanol. The morphological identification was performe individually using morphological keys and descriptions in Feider (1965). Only Ixodes ricinus ticks $(\mathrm{n}=204)$ were used for further analysis. Genomic DNA extraction was performed individually on all ticks following the protocol with ammonium hydroxide decribed by MoránCadenas et al. (2007). All samples were analysed by PCR technique for the diahnosis of B. burgdorferi s.l. and A. phagocytophilum DNA. The PCR for detecting $B$. burgdorferi s.l. was carried out by the method described by Priem et al. (1997) and the amplification was performed targeting the OspA gene (Priem et al., 1997). The PCR for detecting $A$. phagocytophilum was performed by the method described by Courtney et al. (2004), targeting msp2 gene. Positive control samples were used (strains of B. burgdorferi s.s., B. afzelii, B. garinii and DNA extracted from the blood of a dog naturally infected with $A$. phagocytophilum) and laboratory-reared uninfected I. ricinus ticks were used as negative controls. Frequency, prevalence, and its 95\% confidence interval were performed using the EpiInfo 2000 software. The chi-square test was used on the dataset to evalute the statistic significance and was represented by a $p$ value of $<0.05$.

\section{RESULTS AND DISCUSSION}

A total number of 204 ticks (138 females, 46 males, 15 nymphs and 5 larvae) were morphologically identified as I. ricinus. Only $A$. phagocytophilum was detected with a prevalence of $4.4 \%(n=9)$. The number of collected ticks and the prevalence of $A$. phagocytophilum for each county are presented in Tabel 1 . Frequency and prevalence of $A$. phagocytophilum for each developmental stage are shown in Table 2.

Until several years ago, little information was available regarding infection with $A$. phagocytophilum in foxes. In 1999 Pusterla et al. performed serological studies on red foxes from Switzerland showing that these animals can be carriers of $A$. phagocytophilum. More recently, this tick-borne pathogen was detected by PCR in ticks collected from foxes from Hungary, Slovakia and Austria. In Hungary, six of the 112 pools of $I$. ricinus collected from 100 red foxes were found positive to $A$. phagocytophilum (Sréter et al., 2004). In Slovakia the reported prevalence is $4.4 \%$ (Spitalska and Kocianova, 2002) while in Austria, Sixl et al. (2003) found a prevalence of 5.1\%. Most registered values on engorged ticks are comparable

Tab. 1. Number of collected ticks and prevalence of A. phagocytophilum for each county

\begin{tabular}{|c|c|c|c|c|c|}
\hline \multirow{2}{*}{ County } & \multirow{2}{*}{ No of ticks } & \multicolumn{4}{|c|}{ A. phagocytophilum } \\
\hline & & Frequency & Prevalence \% & $95 \% \mathrm{CI}$ & $\mathrm{p}$ \\
\hline Alba & 38 & 2 & 5.3 & $0.6-17.7$ & \multirow{9}{*}{0.0917} \\
\hline Bihor & 17 & 2 & 11.8 & $1.5-36.4$ & \\
\hline Brașov & 96 & 2 & 2.1 & $0.3-7.3$ & \\
\hline Cluj & 2 & 1 & 50 & $1.3-98.7$ & \\
\hline Covasna & 29 & 1 & 3.4 & $0.1-17.8$ & \\
\hline Hunedoara & 1 & 0 & 0 & $0.0-97.5$ & \\
\hline Harghita & 2 & 0 & 0 & $0.0-84.2$ & \\
\hline Mureș & 1 & 0 & 0 & $0.0-97.5$ & \\
\hline Satu Mare & 18 & 1 & 5.6 & $0.1-27.3$ & \\
\hline TOTAL & 204 & 9 & 4.4 & $2.0-8.2$ & \\
\hline
\end{tabular}


Tab. 2. Frequency and prevalence of $A$. phagocytophilum for each developmental stage

\begin{tabular}{cccccc}
\hline \multirow{2}{*}{$\begin{array}{c}\text { Developmental } \\
\text { stage }\end{array}$} & No of ticks & \multicolumn{4}{c}{ A. phagocytophilum } \\
\cline { 3 - 5 } & & Frequency & Prevalence $\%$ & $95 \%$ CI & p \\
\hline Female & 138 & 8 & 5.8 & $2.5-11.1$ \\
\hline Male & 46 & 1 & 2.2 & $0.1-11.5$ \\
\cline { 1 - 4 } Nymph & 15 & 0 & 0 & $0.0-21.8$ & \multirow{2}{*}{0.5524} \\
\hline Larvae & 5 & 0 & 0 & $0.0-52.2$ & \\
\hline TOTAL & 204 & 9 & 4.4 & $2.0-8.2$ & \\
\hline
\end{tabular}

with the ones on questing Ixodes ricinus. Schorn et al. (2011) found a prevalence of $3.9 \%$ to $13.3 \%$, in I. ricinus collected from different public parks from Germany, depending on the habitat and developmental stage. The overall prevalence was $8.8 \%$ in questing $I$. ricinus ticks collected in Norway (Mysterud et al., 2013). Regarding the studies performed on red foxes tissue samples, Ebani et al. (2011) reported a prevalence of $16.6 \%$ after investigating 150 foxes from Center Italy. In that area tick vector is present and positive cases in domestic animal were reported (Ebani et al., 2011).

Red foxes are considered competent reservoir host for B. burgdorferi s.l., but few epidemiological studies are available. Heidrich et al. (1999) found a prevalence of $7.0 \%$ for B. burgdorferi s.l. by PCR in skin samples from foxes in Germany. A study conducted in northeast Spain from 1990 and 2006, on serum samples showed that 7 of the 84 foxes (8.3\%) were positive for Borrelia burgdorferi s.l.. The geographical regions from which animals originated were different in terms of climate and habitat. Positive foxes originated from areas characterised by Atlantic climate, with constant rain and dense forests. The serological negative animals were originated from regions characterized by Mediterranean climate, with lower rainfall in spring and autumn. The authors conclude that the prevalence of $B$. burgdorferi s.l. varies primarily due to differences in habitat, which has a strong influence on tick communities.

In a similar study regarding the prevalence of $B$. burgdorferi s.l. and A. phagocytophilum in I. ricinus ticks collected from hedgehogs from 12 counties of Romania, Dumitrache et al., (2012) identified both pathogens with prevalence of $0.4 \%$ and $12 \%$ respectively. In a more recent study, Matei et al., (2015) found a prevalence of $3.42 \%$ in questing I. ricinus ticks from Romania, after examinig an impressing number of 10,438 samples.
None of the tested samples were positive to B. burgdorferi s.l.. This can be explained on one hand by the number of ticks analyzed or may be a consequence of a low prevalence of the pathogen in both animals and unfed ticks in the habitats from where foxes originated. Regarding the total prevalence for A. phagocytophilum, the value falls within the average values in Europe.

\section{CONCLUSION}

Red foxes are hosts for Ixodes ricinus, the main vector for zoonotic pathogen A. phagocytophilum. The registered prevalence for A. phagocytophilum, is similar to other results obtain in different epidemiological studies from Europe. As foxes represent a good model of sentinel species, further studies on the structure of tick communities correlated with the presence of tick-borne pathogens, can be suggestive for the risk posed for public health.

Acknowledgements. Dr. MOD's work was financed by POSDRU grant no. 159/1.5/S/136893 grant with title: "Parteneriat strategic pentru creșterea calității cercetării științifice din universitățile medicale prin acordarea de burse doctorale și postdoctorale - DocMed.Net_2.0. ADM and GD were supported in this research by a grant from the UEFISCDI grant PCE 236/2011. CMG work was financed by PCCE $7 / 2010$. MOD, GD, CMG, AMI, IAM, ADM are members of the COST Action TD1303 “European Network for Neglected Vectors and Vector-Borne Infections (EURNEGVEC).

\section{REFERENCES}

1. Courtney JW, Kostelnik LM, Zeidner NS, Massung RF (2004) Multiplex real-time PCR for detection of Anaplasma phagocytophilum and Borrelia burgdorferi, J Clin Microbiol., 42:3164-3168.

2. Dumitrache MO,Paștiu AI,Kalmár Z,Mircean V,Sándor AD,Gherman CM,Peștean C,Mihalca AD,Cozma V 
(2012) Northern white-breasted hedgehogs Erinaceus roumanicus as hosts for ticks infected with Borrelia burgdorferi sensu lato and Anaplasma phagocytophilum in Romania. Ticks Tick Borne Dis 4(3):214-217.

3. Ebani VV, Ranieri V, Fratini F, Poli A, Cerri D (2011). Molecular Survey of Anaplasma phagocytophilum and Ehrlichia canis in red foxes (Vulpes vulpes) from Central Italy, J Wildl Dis 3(47):699-703.

4. Feider Z., 1965. Fauna of the Peoples Republic of Romania. Suprafamily Ixodoidea (Ticks). Editura Academiei Republicii Populare Române, Bucharest, pp. 401 (in Romanian).

5. Heidrich J, Schonberg A, Steuber S, Nökler K, Schuize P, Voigt WP, Scheirr E (1999). Investigation of Skin Samples from Red Foxes (Vulpes vulpes) in Eastern Brandenburg (Germany) for the Detection of Borrelia burgdorferi s.l.. Zentbl Bakteriol 289:666-672.

6. Jongejan F, UilenbergG (2004). The global importance of ticks. Parasitol 129, S3-S14.

7. Martinez-Carrasco C, Ruiz de Ybáñez MR, Sagarminaga JL, Garijo MM, Moreno F, Acosta I, Hernández S, Alonso FD (2007). Parasites of red fox (Vulpes vulpes Linnaeus, 1758) in Murcia, southeast Spain. Revue Méd Vét 7(158): 331-335.

8. Matei IA, Kalmár Z, Magdaș C, Magdaș V, Toriay H, Dumitrache MO, Ionică AM, D’Amico G, Sándor AD, Mărcuțan DI, Domșa C, Gherman CM, Mihalca AD (2015) Anaplasma phagocytophilum in questing Ixodes ricinus ticks from Romania. Ticks Tick Borne Dis 6(3):408-13

9. Morán-Cadenas F, Schneider H, Lommano E, Burri C, Moret J, Gern L (2007). A comparison of two DNA extraction approaches in the detection of Borreliaburgdorferi sensu lato from live Ixodes ricinus ticks by PCR and reverse lineblotting. Vector Borne Zoonotic Dis. 7:555-561.

10. Mysterud A, Easterday WR, Qviller L, Viljugrein H, Ytrehus B (2013). Spatial and seasonal variation in the prevalence of Anaplasma phagocytophilum and Borrelia burgdorferi sensu lato in questing Ixodes ricinus ticks in Norway. Parasit Vectors. 6: 187.

11. Priem S, Rittig MG, Kamradt T, Burmester GR, Krause A (1997). An optimized PCR leads to rapid and highly sensitive detection of Borrelia burgdorferi in patients with Lyme borreliosis. J Clin Microbiol 35: 685-690.

12. Pusterla N, Deplazes P, Braun U, Lutz H (1999) Serological evidence of infection with Ehrlichia spp. in red foxes (Vulpes vulpes) in Switzerland. J Clin Microbiol, 37:11681169.

13. Schorn S, Pfister K, Reulen H, Mahling M, Manitz J, Thiel C, Silaghi C (2011), Prevalence of Anaplasma phagocytophilum in Ixodes ricinus in Bavarian public parks, Germany. Ticks Tick Borne Dis 2(4):196-203.

14. Sixl W, Petrovec M, Marth E, Wüst G, Stünzer D, Schweiger R, Avsic-Zupanc T (2003). Investigation of Anaplasma phagocytophila infections in Ixodes ricinus and Dermacentor reticulatus ticks in Austria. Ann NY Acad Sci 990:94-97.

15. Spitalska E, Kocianova E (2002). Agents of Ehrlichia phagocytophila group and other microorganisms coinfecting ticks in southwestern Slovakia.Acta Virol 46:4950.

16. Sréter T, Sréter-Lancz Z, Széll Z, Kálmán D (2004). Anaplasma phagocytophilum: an emerging tick-borne pathogen in Hungary and Central Eastern Europe. Ann Trop Med Parasitol 98(4):401-415. 